\title{
Retinoblastoma-Like Protein 2
}

National Cancer Institute

\section{Source}

National Cancer Institute. Retinoblastoma-Like Protein 2. NCI Thesaurus. Code C29831.

Retinoblastoma-like protein $2(1139 \mathrm{aa}, \sim 130 \mathrm{kDa})$ is encoded by the human RBL2 gene.

This protein plays a role in the regulation of cell division. 